\title{
Influence of Gadget: A Positive and Negative Impact of Smartphone Usage for Early Child
}

\author{
Srinahyanti ${ }^{1 *}$, Yasaratodo $\mathrm{Wau}^{1}$, Imelda Free Unita Manurung ${ }^{1}$, Nur Arjani ${ }^{1}$ \\ $\left\{{ }^{*}\right.$ sdzlaffer@gmail.com $\}$ \\ Faculty of Education, Universitas Negeri Medan, Medan, Indonesia
}

\begin{abstract}
Technology is an important part of human life. Gadgets are a kind of technology that most widely used by humans. Theseinclude smartphones, tablets, iphone, blackberries, laptops and more others. Not only used for communication, gadgetsalso become a trend in today's cultures for life and knowledge. All information and daily activities such as shopping, payment and entertainment are provided by this device. Users of gadgets are very heterogeneous, from old peopleto young child. Many researchers believe that the use of gadgets can have an impact on the growth and development of early childhood. This paper presents the impact gadget usage in early childhood and it also describes parent's role to prevent children from the negative effects of gadget usage.
\end{abstract}

Keywords: Gadget usage, children, technology, parent role

\section{Introduction}

Nowadays, the use of technology is increasing day by day. Human life is dependent on technology. Technology is being implemented in almost every aspect of our lives and we use various technologies to accomplish specific tasks in our lives. One of the results of technology used by many people aresmartphone and tablet. The smartphone facilitates many aspects of daily life and can be very useful and entertaining tool, not only to communicate, but also can be used to shopping activities, banking, search for places and people, game services and others. Therefore, humans today are very dependent on this object.

Research from Growth from Knowledge (GfK) Asia that Indonesia is the country with the biggest market for smartphone products in Southeast Asia in the first quarter of 2012, even smartphone penetration in Indonesia has reached $62 \%$ with sales of more than 1.4 billion. KOMINFO data also states that smartphone users in Indonesia are growing rapidly and the Emarketer Digital Marketing Research Institute estimates that by 2018, the number of active smartphone users in Indonesia is more than 100 million people [1]. From the data, it is known that the magnitude of smartphone usage is also accompanied by the penetration of internet networks and the fulfillment of online-based human needs.

The smartphone usage and needs are not only enjoyed by adults but also children. The needs and interests of smartphones in children are different from adults. In adults' smartphones are used as a communication, lifestyle, search engine, entertainment whereas for children smartphones or tablets are used for playing and entertainment needs (video games, entertainment applications, social media). The most important difference is they do not have 
the ability to use smartphone wisely, so that it is believed that without parental supervision, the smartphone will be a malfunction and have a negative effect on children.

As we know smartphone like a knife, has two sides, on the one hand this device provides benefits and is needed and the other side also creates many potential hazards. If it cannot be handled wisely by parents, it will damage the next generation. The development of gadgets is unavoidable, but adults must be able to educate without having to seize children's rights to be able to access digital information so that the gadget becomes the effective device.

\section{Methodology}

\subsection{Use of a Smartphone Gadget}

Gadgets are electronic instruments that have certain practical purposes and functions especially helping and facilitating human work [2]. Gadgets are small applications that run on the Windows operating system [2]. Examples of gadget categories that are often found in Indonesia are smartphones, cellphones, blackberries, tablets and computers.

In Indonesia, gadgets have been used by many people even used by early childhood. The results of the study stated that $42.1 \%$ of preschoolers were exposed to relatively high gadgets. The use of gadgets in preschoolers is watching videos or playing games [3].

\subsection{Development of Early Childhood}

Early childhood is a child between the ages of 0-5 years [4], while National Association for the Education of Young Children (NAEYC) states that up to 8 years old children are still classified as early childhood. Early childhood is unique, expresses its behavior relatively spontaneously, egocentric, enthusiastic, explorative, has a high curiosity and is adventurous. Early childhood is often called the golden age because all potential can grow rapidly along with the development of brain volume up to $80 \%$ at this time. Children are excellent imitators rather than excellent voters, meaning that many children can imitate the words and behavior of parents, but have not been able to choose what words and actions are better and right for them to use.

Early childhood has a growing and developing period that must be considered. The developmental aspects of early childhood include; motor physical development, language development, cognitive development, emotional development, social development, religious and moral development and artistic development. Parents and other adults are the most important influence ona child's development. Parent can model and teach the skills that will help them to successfully complete the developmental tasks of their age well.

\section{Result and Discussion}

\subsection{Positive Impact Smartphone Usage for children}

Based on the results of research conducted by The Asian Parent Insight in November 2014, as many as $98 \%$ of 2,714 parents in Southeast Asia allowed their children to access technology in the form of computers, smartphones and tablets. This research was conducted on parents who have children aged 3-8 years and come from Singapore, Malaysia, Indonesia, Philippines and Thailand. The results of the survey stated that the reason parents allowed their children to play gadgets for educational purposes. But the reality is that most smartphone and 
tablet gadgets are used by children for entertainment / play [5]. Here are the benefits of smartphone gadgets for child development:

\section{a. Motor Physical Exercise}

The use of gadgets or smartphones can be used as an exercise in fine motor physical skills in early childhood. These fine motor skills are skills related to small muscles such as the wrist, fingers, toes, lips and tongue. When early childhood play on smartphones or tablets and other gadgets, they will learn to coordinate finger movements [6] and use their hands more quickly and become effesient in it in a short time

\section{b. Increase of Knowledge}

When using a gadget in the form of a smartphone or tablet, children can increase their knowledge about many things. Children learn to know lots of pictures and writing and various colors.

\section{c. Improve of Cognitive Skills}

Children's cognitive skills are the child's ability to process information, ability to remember and simple reasoning and communicate. When children play games on applications that are available on smartphones or educational program, at that time the child will give time for his brain to think and process information and forwarded to the brain for processing or analysis. This is also supported by several studies which mention that the gadget has a positive impact on the ability of investigation, strategic thinking and creativity thinking [7].

The activity of playing games on a smartphone or viewing interactive videos provided on smartphones is much more fun and interesting for children because it is presented in the form of audio-visual media.

\section{d. Train Mental Attitude Ready to Compete}

When a child plays a game, he will recognize winning and losing. This activity can introduce it to a struggle and effort. Children will be more enthusiastic and enthusiastic to get the results they want.

\subsection{Negative Impact of Smartphone Usage for Children \\ a. Obesity and Physical Damage}

Children who excessively use smartphone gadgets will cause obesity. This is supported by the results of research showing pre-school age children with high intensity of gadget use have a 2.1 times greater chance of being obese compared to preschoolers with low gadget usage [8]. The World Health Organization (WHO) also states that one of the factors that causes child obesity is increased sedentary behavior (behavior is not much movement or lack of physical activity). Taking a tablet or smartphone all the time, a child cannot control the normal food intake. Either they eat too quickly or too much since they are concentrated on the screen, not on the meal.

As we know, physical activity held regularly can be beneficial to strengthen the heart, blood vessels and body and brain systems that are fitter. Physical damage such as eye pain is also a threat to early childhood. The high level of eye activity on the smartphone screen will damage the function of the eye, the eyes become tired and uncomfortable. Dr. D.A.N Canara Sari, SP. M quoted by Eva Erviana also added that using a gadget for a long time and close range could cause eye minus [9]. 


\section{b. Addiction}

Early childhood who have the activity of staring at screen-based media and gadgets such as smartphones and tablets to play games longer and increase in duration every day are signs of addiction. This addiction occurs due to things or things that make children happy which will stimulate the brain to produce dopamine excessively. Excessive amounts of dopamine will disrupt the workings of the hypothalamus, the part of which is responsible for regulating emotions and moods that make us feel very happy and over-confident.

\section{c. Less Concentrate}

Children who play many video games in smartphone or most of their time online tend to have less an ability to focus thank kids who use gadget minimally.

\section{d. Speech Delay}

Speech delay is one of the causes of developmental disorder in child language. Speech delay is caused by excessive use of gadgets. When a child uses a gadget such as a smartphone, the child will focus on looking at the screen and not making social contact whereas contact and social communication are needed by children to develop their language skills and speech.

The study presented at the Pediatric Academic Societies Meeting in San Francisco explained that Birken, a pediatrician at the Hospital for Sick Children Canada found a connection to the use of gadgets in the ability to speak to children. In 2011-2015, Birken conducted observation and question and answer to parents who have children aged 2-24 months regarding the duration of time given to children to watch through the gadget screen, $20 \%$ of the children studied used a gadget for at least 28 minutes every day. The result they found every additional 30 minutes of time used to play gadgets can increase the risk of late speaking up to $49 \%$ [10]

The results of another study of 714 children aged 24-60 months inTambakrejo,Surabaya also proved a significant relationship between children's speaking ability and gadget use in children [2].

Social disability. The research results show that most children have the habit of playing gadgets more than 1 hour each day experiencing degradation of social development [11]. Children with high gadget activity will become apathetic to the environment, the level of aggression will also increase.

Added, in an article by Dr. Gary Small, director of the longevity center at the University of California says that if children spend much time on technology and less time with people, it hinders interaction and disrupts the normal communication skills development on children.

\section{e. Radiation Exposure}

According to the 2014 report of the World Health Organization (WHO), cellphone and other wireless devices are considered catagory risk because of their radiation emission [15]. In December 2013, Dr Anthony Miller from The University of Toronto's School of Public Health revealed that radio frequency exposure is clearly a threat to childen.

\section{f. Attention Deficit Hyperactivity Disorder Problem}

Phones and tablets becoming a part of daily life. According medical expert, the overuse of gadgets in children can contribute to ADHD-like symptoms. According to Centers for Disease Control, Children who have ADHD have trouble playing attention and be overly active.

The lastest study, published in the Journal of the American Medical Association has linked ADHD to teens who frequently use electronic device. Out of 2586 student who 
consumed multiple types of digital media were about twice as likely to report strong ADHD as their peers [12].

\section{g. The Role of Parent in Monitoring Smartphone Usage}

Nowadays the use of gadgets cannot be avoided, therefore parents and adults around the child have avery important role. At the age of 0-2 years, gadgets actually haven't an important function and a positive impact on them. However, if conditions are not possible and the child exposed to electronic screen media, parents must be able to aid so that there is no misuse of the gadget and have a negative impact on the child.

Here are some tips to help head off these problems. Make sure parents have enough time to assist children using gadgets (smartphones) in a relatively short time. The ideal time for children to use gadgets at an early age is 5-30 minutes with an intensity of 1-2 times per day [3].

Parents must take control of the gadget (smartphone) including the mastery of the existing application and the content provided on the smartphone. Lots of inappropriate contentfor children so that parents' wisdom is needed.

Don't let the child use the gadget in a private roomlonely, such as the first point that the use is still being assist by parents. Make sure the position of the child playing or using the gadget is correct with the right duration and visibility. Dont let them use gadgets smartphone in the dark on in sunlight and while using smartphone or other pesonal device, the eye should be at least 20 inches away from the screen. Dont let the children too close to the screen. Encourage children to play outdoors. Facilitating outdoor play activities for children, playing outside can divert children from smartphones or other gadgets and playing outdoors with pet or other kids is more fun than watching video or gaming

\section{Conclusion}

This isn't to say that gadgets smartphonr is bad, or that children should never use gadget. Being a parent and child in the era of globalizationis full of challenges. The important thing to understand is the higher the need to use a gadget must be accompanied by the ability to master the gadget itself. Gadgets provide a positive oppurtunity but it has a negative impact on children and their future lives too. Parentsmust have to supervise, monitorand control children using gadgets responsibly and wisely.

\section{References}

[1] M. Nindya, "Hubungan Durasi Penggunaan Gadget terhadap Perkembangan Sosial Anak Pra Sekolah di TK PGRI 33 Sumurboto Banyumanik," Skripsi, 2017.

[2] Julia, "Handheld Screen Time Linked with Speech Delays in Young Children," Present. Pedriatic Acad. Soc. Meet., 2017.

[3] C. Rowan, "The Impact of Technologi on Child Sensory Motor Development," 2003.

[4] S. T. et al Fajar, "Intensitas Penggunaan Gadget Pada Anak Pra Sekolah Yang Kelebihan Berat Badan di Jogyakarta," BKM J. Community Med. Public Heal., 2017.

[5] Y. et al Trinika, "Pengaruh Penggunaan Gadget terhadap Perkembangan Psikososial anak usia prasekolah (3-6 tahun) di TK Swasta Kristen Emmanuel Tahun Ajaran 2014-2015,” vol. 3, no. $1,2015$. 
[6] J. R. Muduli, "Addiction to technological gadgets and its impact on Health and Lifestyle: a Study on College Student," 2014. .

[7] L. F. Jonathan, L. P., \& Andrew, "Depression in Children and adolescents' Development," Appl Dev. Psychol, vol. 22, pp. 7-30, 2016.

[8] A. Nurmasari, "Hubungan Intensitas Penggunaan Gadge dengan Keterlambatan Perkembangan pada Aspek Bicara dan Bahasa pada Balita di Kelurahan Tambakrejo," Skripsi Univ. Erlangga, 2016.

[9] E. Erviana, "Gangguan Mata akibat Keseringan Main Gadget," 2014.

[10] I. Rahmayani, "Indonesia Raksasa Teknologi Digital Asia," 2015. .

[11] K. R. et al Chaelin, "Association of Digital Media Use with Subsequent Symptoms of Attention Deficit/Hyperactivity Disorder Among Adolescents," J. Am. Med. Assoc., 2018.

[12] R. Umah, Hidayatul \& Yulia, "Gadget dan Speech Delay: Kajian Perkembangan Kemampuan Berbahasa Anak," Indones. J. Islam. Eraly Child. Educ., 2018. 